\title{
Study on Morpho-Physical Characters of Mango Flower Varieties / Hybrids in Kodur Agro-Climatic Conditions
}

\author{
M.D. Saheda*, M. Balahussaini, M. Ramaiah and M. Balakrishna
}

College of Horticulture, Ananatharajpet, Dr. YSR Horticultural University, West Godhavari, Andhra Pradesh, India

*Corresponding author

\author{
A B S T R A C T
}

\section{Keywords \\ Mangifera indica L., Marpho- Physical, Inflorescences characteristics \\ Article Info \\ Accepted: 04 February 2019 Available Online: 10 March 2019}

\begin{abstract}
Inflorescence characteristics of 30 mango genotypes were studied during the period 2013 to 2014. There were distinct variations among the findings of the germplasm on inflorescence characters. Wide variations were observed in relation to the length of the inflorescence, width of the inflorescence, total number of flowers per inflorescence, number of male flowers per inflorescence, $\%$ perfect flower, $\%$ fruit set per panicle ranging from $13.17 \mathrm{~cm}$ to $43.17 \mathrm{~cm}, 10.03 \mathrm{~cm}$ to $32.23 \mathrm{~cm}, 887.33$ to $4242.00,840.00$ to $3655.33,3.53 \%$ to 37.33 and $3.35 \%$ to 35.07 , respectively. The mango cv. Bangalora was top of the list in case of the length of the inflorescence $(43.17 \mathrm{~cm})$, width of the inflorescence $(32.23 \mathrm{~cm})$, total number of flowers per inflorescence $(4242.00)$, number of male flowers per inflorescence (3655.33). The maximum \% of perfect flower $(37.33 \%)$ and percentage of fruit set per panicle $(35.07 \%)$ was noted in mango cv. Neelum.
\end{abstract}

\section{Introduction}

Mango (Mangifera indica L.), a member of the family Anacardiaceae, is one of the choicest fruits in the world (De Candolle, 1904 and Popenoe, 1927). It has medium calorific and high nutritional values. Mango exhibits wide variations in flowering and fruiting due to its strong dependency on environment. Flowering of mango is an important physiological event that sets the start of fruit production. Flowering is decisive factor in the productivity of mango. The process associated with mango involves shoot initiation followed by floral differentiation of apical bud, and panicle emergence (Murti and Upreti, 2000). Variability of mango flowering depends upon cultivar, tree age, environmental condition and growth conditions in the dry or humid tropics (Singh, 1960). Mango grows in almost all parts of Andhra Pradesh but the commercial and good quality grafted mangoes with known varietal identity are mostly confined in Rayalaseema districts. Moreover, studies relating to the performance of such varieties grown in those areas are scanty. So, the need exists to assess the performance of elite varieties under that area. Again, 
characterization is an important aspect for documentation of the performance of the studied cultivars, which would help to introduce, select and improve the existing mango varieties. Therefore, an attempt was made to study the physio-morphology of inflorescences characters of 30 germplasm in the mango orchard of Horticulture College and Research Institute, Anantharajupet, Kodur, YSR (dist.).

\section{Materials and Methods}

The present experiment was conducted in a pre-established orchard of Horticulture College and Research Institute, Anantharajupet, Kodur, YSR (dist.), Andhra Pradesh during 2013 to September 2014.

The experiment was conducted on 30 mango germplasm. The experiment was laid out in a CRBD with three replications, where a single uniform tree constituted the unit of replication. Panicles from full bloomed tree were collected randomly from the selected plants. Twelve inflorescences from each of the selected germplasm were tagged for reading their physical characteristics like length of the inflorescence, width of the inflorescence, total number of flowers per inflorescence, number of male flowers per inflorescence, Percentage of hermaphrodite flowers per inflorescence, sex ratio (male flower to hermaphrodite flowers) and percentage of fruit set per inflorescence.

Data on different morphological parameters from 30 mango genotypes were recorded according to the descriptors for mango (IPGRI, 2006). The length of the inflorescences was measured from the base to tip and the width of the inflorescences was measured at the broadest part of the base of the inflorescences. Total numbers of male and hermaphrodite flowers are counted with the help of hand lens.
The percentage of hermaphrodite flowers was calculated by using the following formula.

Per cent of hermaphrodite flowers $=$

Number of hermaphrodite flowers

Total number of flowers

The ratio of male flowers to hermaphrodite flowers was calculated as follows:

Sex ratio $=$

Number of male flowers

Number of hermaphrodite flowers

Fruit set was recorded at marble stage in twelve selected tagged panicles in a tree and the mean values were expressed in percentage.

Percentage of fruit set per inflorescence $=$ Number of fruits at marble stage x100

Total number of flowers

\section{Results and Discussion}

\section{Inflorescence characteristics}

A wide variation was noticed in colour and shape of the inflorescence among the varieties/hybrids and all the varieties/hybrids produced pentamerous type of flowers at terminal position. The inflorescence colour in most of the varieties varied from light green to light green with red patch. Khader, Bangalora, Royal special, Suvarnarekha, Swarna Jehangir exhibited crimson colour of inflorescence, Dashehari, Neeluddin and Himampasand showed light green colour inflorescence, Neelum, Yelamanda, Cherukurasam, Peddarasam, Allipasand, K.O.15, Mallika expressed yellowish green coloured inflorescence (Fig. 1). 
Table.1 Morphological characters of flowers of various mango varieties and hybrids

\begin{tabular}{|c|c|c|c|c|}
\hline Varieties & $\begin{array}{l}\text { Inflorescence } \\
\text { colour }\end{array}$ & Inflorescence shape & $\begin{array}{l}\text { Inflorescence } \\
\text { position }\end{array}$ & Type of flower \\
\hline $\mathrm{T}_{1}$ : Khader & Crimson & Broadly pyramidal & Terminal & Pentamerous \\
\hline $\mathbf{T}_{2:}$ Bangalora & Crimson & Pyramidal & Terminal & Pentamerous \\
\hline $\mathbf{T}_{3:}$ Dashehari & Light green & Conical & Terminal & Pentamerous \\
\hline $\mathbf{T}_{4:}$ Himampasand & Light green & Broadly pyramidal & Terminal & Pentamerous \\
\hline$T_{5}:$ Neelum & Yellowish green & Broadly pyramidal & Terminal & Pentamerous \\
\hline$T_{6}: \quad$ Kesar & Light red & Broadly pyramidal & Terminal & Pentamerous \\
\hline $\mathbf{T}_{7}:$ Royal special & Crimson & Broadly pyramidal & Terminal & Pentamerous \\
\hline $\mathbf{T}_{8:}$ Mulgoa & Green with red patch & Broadly pyramidal & Terminal & Pentamerous \\
\hline T9: $_{9}$ Athimadhuram & Light red & Pyramidal & Terminal & Pentamerous \\
\hline $\mathbf{T}_{10:}$ Yelamanda & Yellowish green & Broadly pyramidal & Terminal & Pentamerous \\
\hline $\mathbf{T}_{11:}$ Dilpasand & Dark red & Pyramidal & Terminal & Pentamerous \\
\hline$T_{12}:$ Pulihora & Dark red & Conical & Terminal & Pentamerous \\
\hline $\mathbf{T}_{13:}$ Cherukurasam & Yellowish green & Broadly pyramidal & Terminal & Pentamerous \\
\hline $\mathbf{T}_{14:}$ Chinnarasam & Pink & Conical & Terminal & Pentamerous \\
\hline $\mathbf{T}_{15:}$ Baneshan & Green with red patch & Broadly pyramidal & Terminal & Pentamerous \\
\hline$T_{16:}$ Peddarasam & Yellowish green & Broadly pyramidal & Terminal & Pentamerous \\
\hline $\mathbf{T}_{17:}$ Allipasand & Yellowish green & Broadly pyramidal & Terminal & Pentamerous \\
\hline $\mathrm{T}_{18:}$ Prodduturiavakai & Green with red patch & Broadly pyramidal & Terminal & Pentamerous \\
\hline $\mathbf{T}_{19:}$ Kalepad & Green with red patch & Pyramidal & Terminal & Pentamerous \\
\hline $\mathbf{T}_{20}:$ Panchadarakalasa & Green with red patch & Pyramidal & Terminal & Pentamerous \\
\hline $\mathbf{T}_{21}$ :Suvarnarekha & Crimson & Pyramidal & Terminal & Pentamerous \\
\hline $\mathbf{T}_{22}$ :Jehangir & Dark red & Conical & Terminal & Pentamerous \\
\hline$T_{23}:$ K.O.5 & Light red & Pyramidal & Terminal & Pentamerous \\
\hline$T_{24}:$ K.O.15 & Yellowish green & Pyramidal & Terminal & Pentamerous \\
\hline$T_{25}:$ Neeleshan & Dark red & Conical & Terminal & Pentamerous \\
\hline$T_{26}:$ Neeluddin & Light green & Conical & Terminal & Pentamerous \\
\hline $\mathbf{T}_{27}: \mathrm{KMH}-1$ & Light red & Pyramidal & Terminal & Pentamerous \\
\hline $\mathbf{T}_{28:}$ SwarnaJehangir & Crimson & Pyramidal & Terminal & Pentamerous \\
\hline $\mathbf{T}_{29:}$ A.U.Rumani & Green with red patch & Conical & Terminal & Pentamerous \\
\hline $\mathbf{T}_{30:} \quad$ Mallika & Yellowish green & Broadly pyramidal & Terminal & Pentamerous \\
\hline
\end{tabular}


Table.2 Inflorescence length $(\mathrm{cm})$, width $(\mathrm{cm})$, total number of flowers and total number of male flowers per inflorescence of different varieties and hybrids of mango

\begin{tabular}{|c|c|c|c|c|}
\hline Varieties & $\begin{array}{c}\text { Length of the } \\
\text { inflorescence }(\mathrm{cm})\end{array}$ & $\begin{array}{c}\text { Width of the } \\
\text { inflorescence }(\mathrm{cm})\end{array}$ & $\begin{array}{l}\text { Total number of } \\
\text { flowers per } \\
\text { inflorescence }\end{array}$ & $\begin{array}{c}\text { Number of male } \\
\text { flowers per } \\
\text { inflorescence }\end{array}$ \\
\hline$T_{1}:$ Khader & 28.00 & 21.00 & 3443.33 & 3018.33 \\
\hline $\mathbf{T}_{2:}$ Bangalora & 43.17 & 32.23 & 4242.00 & 3655.33 \\
\hline $\mathbf{T}_{3:}$ Dashehari & 29.73 & 25.93 & 2314.00 & 2160.00 \\
\hline $\mathbf{T}_{4:}$ Himampasand & 25.27 & 16.77 & 2406.00 & 2096.00 \\
\hline $\mathbf{T}_{5}:$ Neelum & 22.67 & 19.53 & 1631.67 & 1020.33 \\
\hline $\mathbf{T}_{6:}:$ Kesar & 28.37 & 26.40 & 3095.00 & 2936.00 \\
\hline $\mathbf{T}_{7}:$ Royal special & 20.00 & 14.30 & 2475.33 & 2254.00 \\
\hline $\mathbf{T}_{8}:$ Mulgoa & 21.00 & 18.67 & 2013.33 & 1886.33 \\
\hline T $_{9}$ Athimadhuram & 17.64 & 14.20 & 2023.33 & 1864.00 \\
\hline $\mathbf{T}_{10:}$ Yelamanda & 24.10 & 22.53 & 1559.67 & 1327.67 \\
\hline $\mathbf{T}_{11:}$ Dilipasand & 13.90 & 11.10 & 1219.00 & 1159.67 \\
\hline$T_{12}:$ Pulihora & 30.33 & 26.67 & 3464.33 & 3079.33 \\
\hline$T_{13:}$ Cherukurasam & 21.43 & 17.23 & 2017.00 & 1505.67 \\
\hline $\mathbf{T}_{14:}$ Chinnarasam & 22.23 & 20.00 & 1652.33 & 1500.00 \\
\hline $\mathbf{T}_{15:}$ Baneshan & 36.17 & 28.80 & 3530.00 & 3406.33 \\
\hline $\mathbf{T}_{16:}$ Peddarasam & 32.00 & 24.83 & 3491.67 & 3086.00 \\
\hline $\mathbf{T}_{17:}$ Allipasand & 23.87 & 20.77 & 3353.67 & 3025.00 \\
\hline $\mathbf{T}_{18:}$ Prodduturiavakai & 27.67 & 22.00 & 2886.33 & 2717.00 \\
\hline $\mathbf{T}_{19:}$ Kalepad & 13.66 & 11.47 & 1146.67 & 857.00 \\
\hline $\mathbf{T}_{20}$ :Panchadarakalasa & 13.23 & 11.33 & 1139.67 & 850.67 \\
\hline $\mathbf{T}_{21}:$ Suvarnarekha & 27.74 & 23.64 & 1925.67 & 1837.33 \\
\hline$T_{22}:$ Jehangir & 13.17 & 10.03 & 887.33 & 840.00 \\
\hline $\mathrm{T}_{23}: \mathrm{K} . \mathrm{O.5}$ & 13.83 & 11.73 & 1204.33 & 1105.00 \\
\hline$T_{24}:$ K.O.15 & 14.83 & 12.47 & 1244.00 & 1139.67 \\
\hline \multicolumn{5}{|l|}{ Hybrids } \\
\hline$T_{25}:$ Neeleshan & 17.47 & 12.13 & 1576.00 & 1447.67 \\
\hline $\mathbf{T}_{26}:$ Neeluddin & 18.30 & 14.57 & 1299.33 & 1167.67 \\
\hline $\mathbf{T}_{27}: \quad \mathrm{KMH}-1$ & 40.00 & 30.63 & 3969.33 & 3526.00 \\
\hline $\mathbf{T}_{28:}$ SwarnaJehangir & 25.73 & 15.67 & 2374.00 & 2241.00 \\
\hline T $_{29:}$ A.U.Rumani & 24.37 & 21.33 & 1565.00 & 1446.00 \\
\hline $\mathbf{T}_{\mathbf{3 0}:}$ Mallika & 31.40 & 25.40 & 3504.33 & 3097.00 \\
\hline S.Em \pm & 0.33 & 0.31 & 27.33 & 23.03 \\
\hline $\mathrm{CD}(\mathrm{P}=0.05)$ & 0.78 & 0.75 & 64.59 & 52.07 \\
\hline
\end{tabular}


Table.3 Percentage of hermaphrodite flowers per inflorescence $(\%)$, sex ratio (male to hermaphrodite flowers) and percentage of fruit set per inflorescence at marble stage of different varieties and hybrids of mango

\begin{tabular}{|c|c|c|c|}
\hline Varieties & $\begin{array}{c}\text { Percentage of } \\
\text { hermaphrodite flowers } \\
\text { per inflorescence }(\%)\end{array}$ & $\begin{array}{c}\text { Sex ratio (male to } \\
\text { hermaphrodite flowers) }\end{array}$ & $\begin{array}{l}\text { Percentage of fruit set } \\
\text { per inflorescence at } \\
\text { marble stage }\end{array}$ \\
\hline$T_{1}:$ Khader & 12.20 & 7.72 & 11.46 \\
\hline $\mathbf{T}_{2:}$ Bangalora & 13.87 & 6.21 & 13.03 \\
\hline $\mathbf{T}_{3:}$ Dashehari & 6.67 & 14.00 & 6.27 \\
\hline $\mathbf{T}_{4:}$ Himampasand & 11.45 & 6.74 & 10.76 \\
\hline$T_{5}:$ Neelum & 37.33 & 1.68 & 35.07 \\
\hline$T_{6}:$ Kesar & 5.15 & 18.85 & 4.83 \\
\hline $\mathbf{T}_{7}:$ Royal special & 9.11 & 10.27 & 8.56 \\
\hline $\mathbf{T}_{8}$ : Mulgoa & 6.29 & 15.01 & 5.91 \\
\hline T9: $_{9}$ Athimadhuram & 6.62 & 15.11 & 6.22 \\
\hline$T_{10:}$ Yelamanda & 14.90 & 5.73 & 14.00 \\
\hline$T_{11:}$ Dilipasand & 4.88 & 19.87 & 4.58 \\
\hline $\mathrm{T}_{12}:$ Pulihora & 10.91 & 8.27 & 10.25 \\
\hline $\mathbf{T}_{13:}$ Cherukurasam & 25.33 & 2.97 & 23.78 \\
\hline $\mathrm{T}_{14:}$ Chinnarasam & 9.18 & 9.89 & 8.63 \\
\hline $\mathbf{T}_{15:}$ Baneshan & 3.53 & 27.54 & 3.35 \\
\hline $\mathbf{T}_{16:}$ Peddarasam & 11.56 & 7.61 & 10.86 \\
\hline $\mathbf{T}_{17:}$ Allipasand & 9.77 & 9.26 & 9.37 \\
\hline $\mathrm{T}_{18:}$ Prodduturiavakai & 5.88 & 16.07 & 5.52 \\
\hline $\mathbf{T}_{19:}$ Kalepad & 25.34 & 3.02 & 23.82 \\
\hline $\mathbf{T}_{20}$ :Panchadarakalasa & 23.40 & 3.20 & 21.99 \\
\hline$T_{21}$ :Suvarnarekha & 4.60 & 20.97 & 4.32 \\
\hline $\mathbf{T}_{22}$ :Jehangir & 5.26 & 31.05 & 4.94 \\
\hline$T_{23}:$ K.O.5 & 7.89 & 21.75 & 7.41 \\
\hline$T_{24}:$ K.O.15 & 11.90 & 7.42 & 11.18 \\
\hline \multicolumn{4}{|l|}{ Hybrids } \\
\hline$T_{25}:$ Neeleshan & 8.15 & 11.31 & 7.66 \\
\hline$T_{26}:$ Neeluddin & 10.14 & 9.03 & 9.52 \\
\hline $\mathbf{T}_{27}: \quad \mathrm{KMH}-1$ & 11.87 & 7.95 & 11.15 \\
\hline $\mathbf{T}_{28:}$ SwarnaJehangir & 5.57 & 17.01 & 6.23 \\
\hline T 29: $_{\text {: A.U.Rumani }}$ & 8.30 & 11.63 & 7.80 \\
\hline$T_{30:}$ Mallika & 13.33 & 7.60 & 12.53 \\
\hline S.Em \pm & 0.33 & 0.80 & 0.31 \\
\hline $\mathrm{CD}(\mathrm{P}=0.05)$ & 0.78 & 1.90 & 0.74 \\
\hline
\end{tabular}



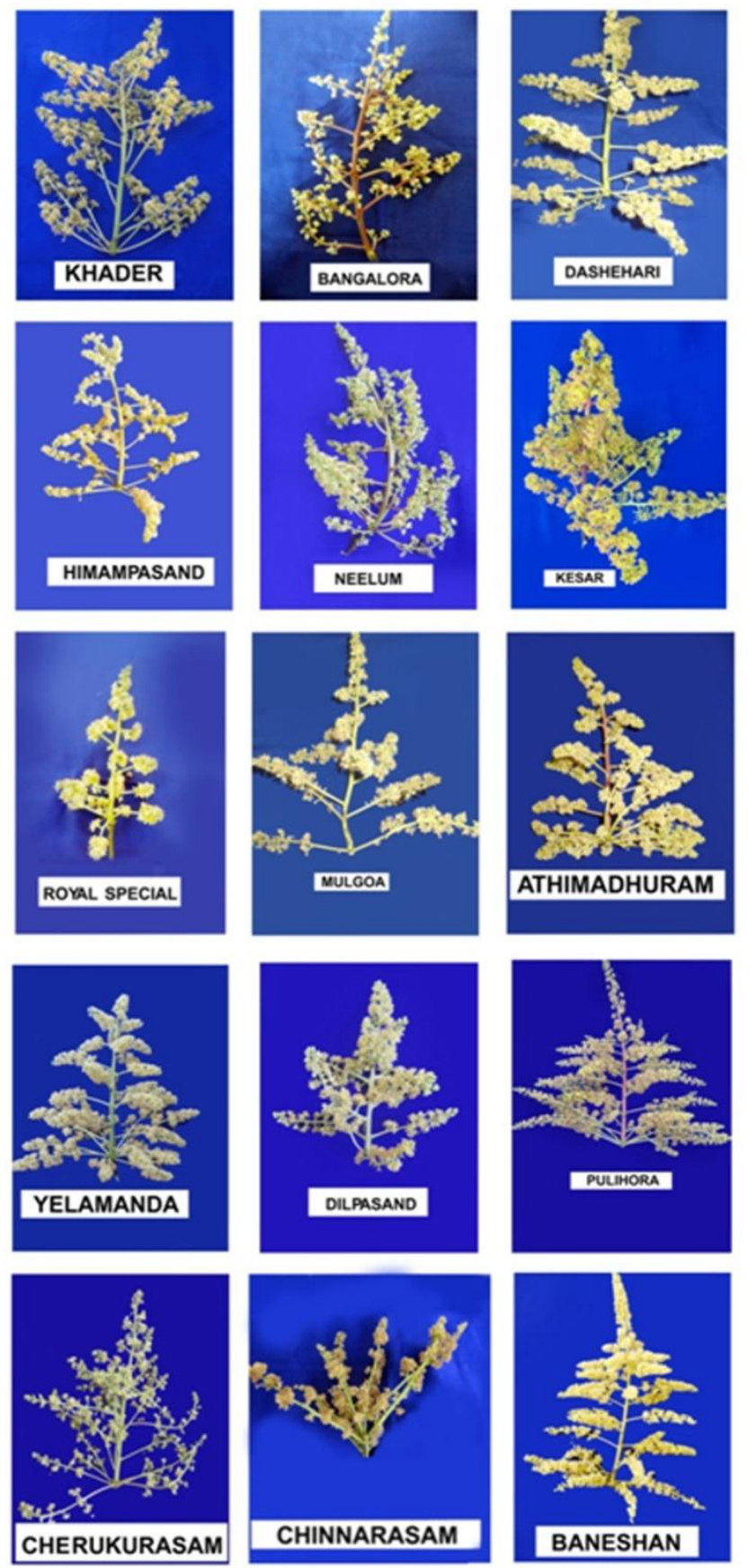

Fig. 1(a):Different inflorescence of mango verieties selected for the study 

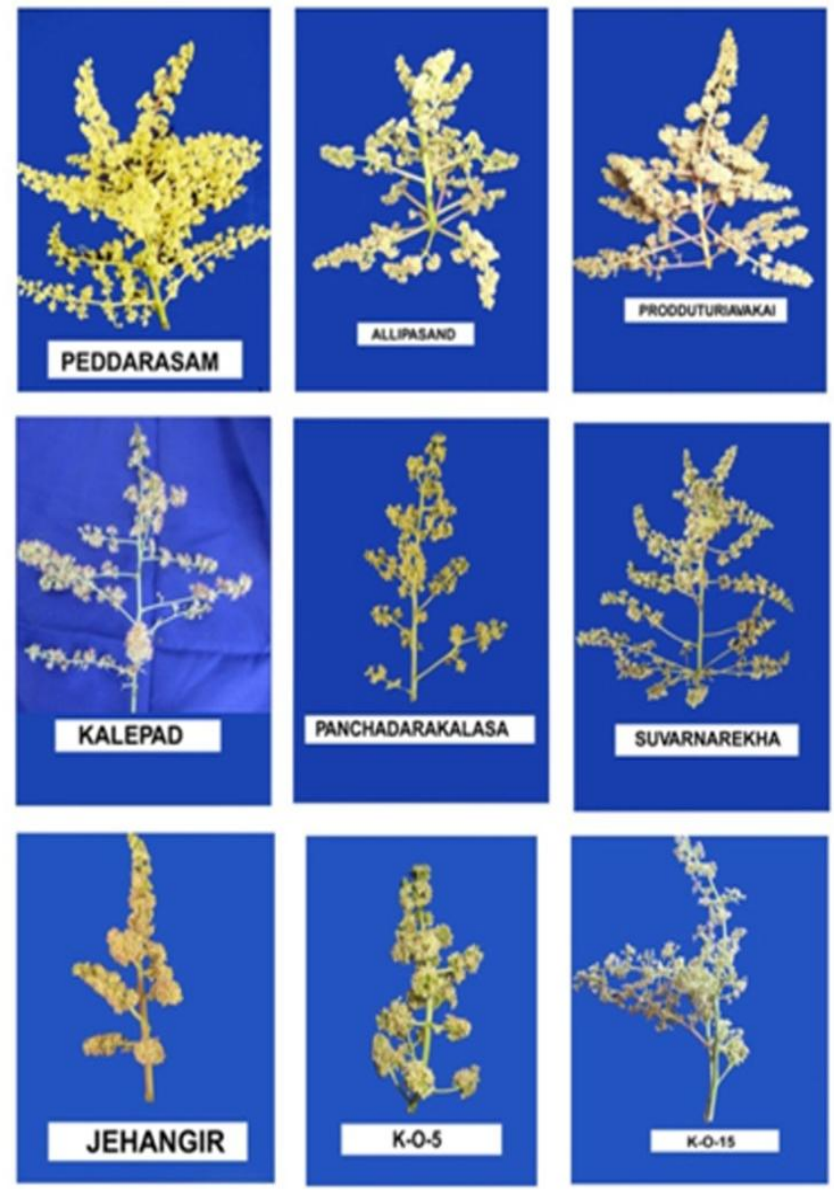

Fig. 1(b):Different inflorescence of mango verieties selected for the study
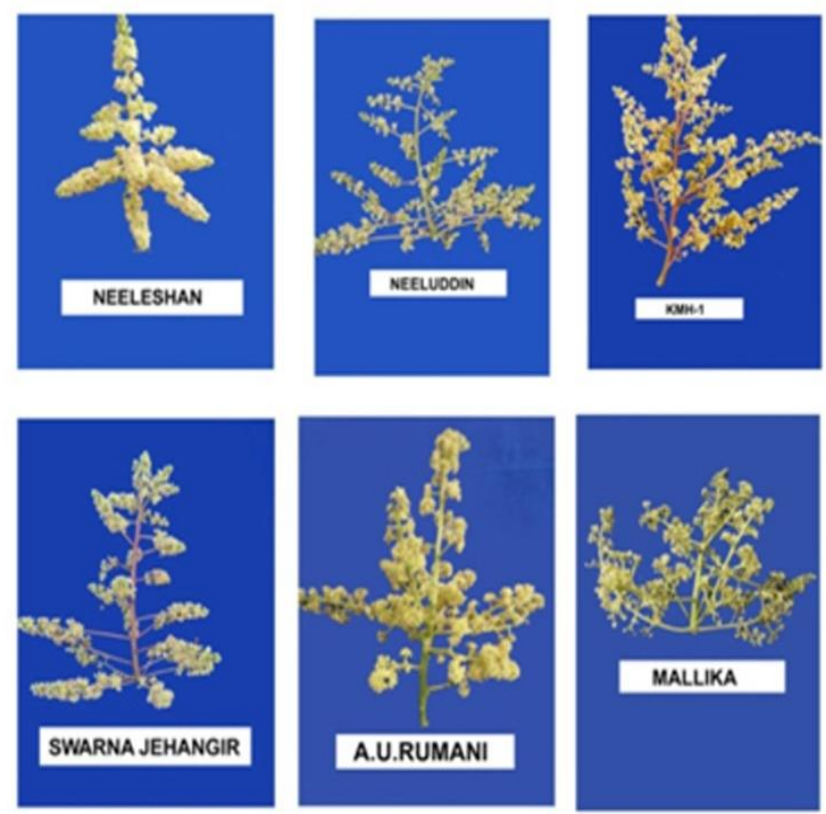

Fig. 1(c):Different inflorescence of mango hybrids selected for the study 


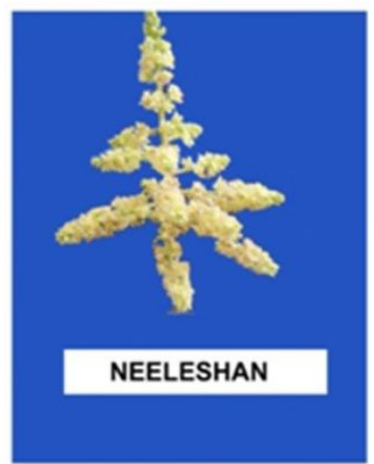

Conical inflorasence shape in cv. Neeleshan

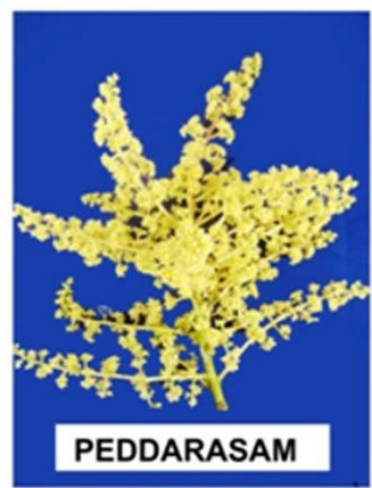

Broadly pyramidal inflorasence shape in cv. Peddarasam

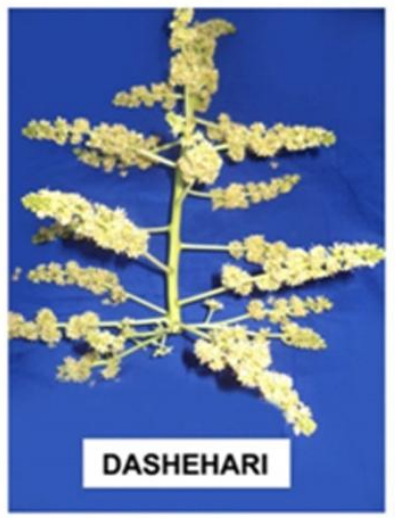

Pyramidal inflorasence shape in cv. Dashehari

Fig.2 : Variability for mango varities/hybrids inflorescence shape 


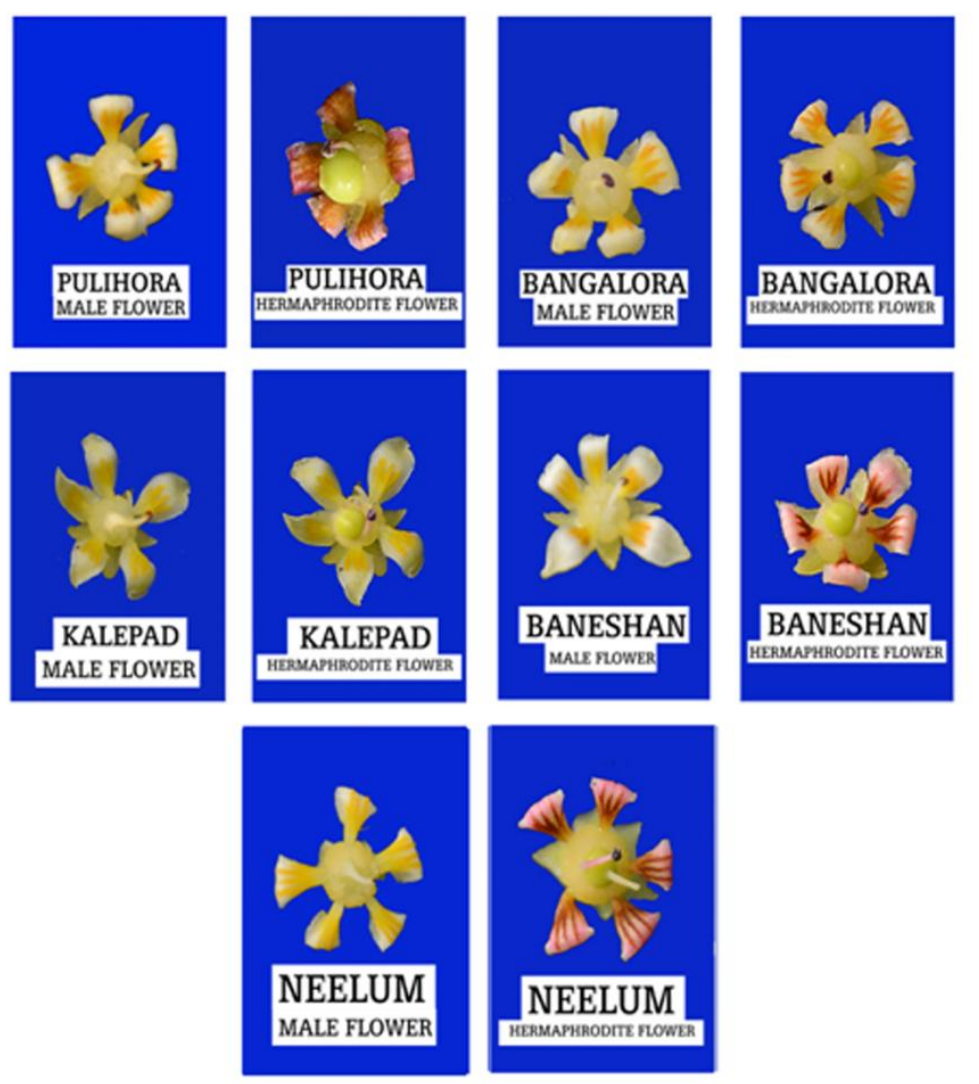

Fig.3 :male and hermaphrodite flowers in different cultivars of mango inflorescence
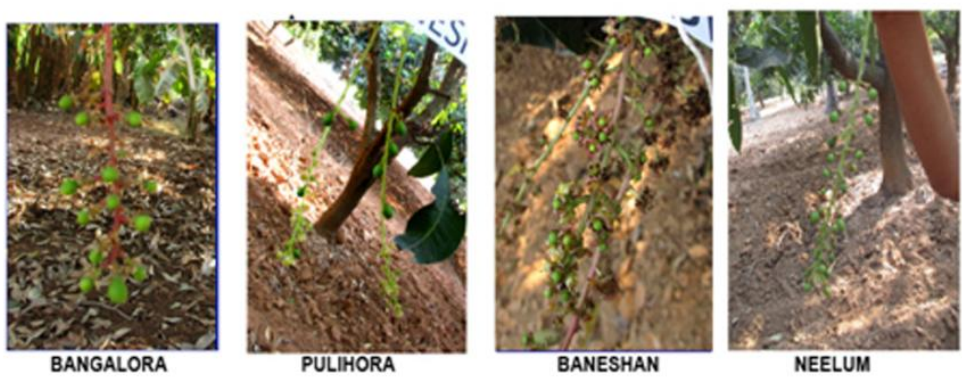

Fig. 4 :per centage of fruit set per inflorescence in different cultivars of mango

Three varieties viz., Kesar, K.O.5, KMH-1 and Athimadhuram recorded light red coloured inflorescence, Mulgoa, Baneshan, Prodduturiavakai, Kalepad, A.U. Rumani and Panchadara Kalasa had inflorescence colour of green with red patches, one variety chinnarasam showed pink colour and Dilpasand, Pulihora, Jehangir and Neeleshan had dark red colour inflorescence (Table 1). Similar findings also reported by Naik et al., (1950). Majumder and Sharma (1990) reported that the flowering color varied with the growing locations (Fig. 2 and 3).

From the table 1 it was observed that, among 30 mango genotypes Khader, Himampasand, Neelum, Kesar, Royal special, Baneshan, Mulgoa, Yelamanda, Cherukurasam, Peddarasam, Allipasand, Prodduturiavakai and Mallika exhibited broadly pyramidal shaped inflorescence, Bangalora, Athimadhuram, Panchadarakalasa, Dilpasand, 
Suvarnarekha, K.O.5, Kalepad, K.O.15, KMH-1, Swarna Jehangir showed pyramidal shaped inflorescences and Dashehari, Pulihora, Chinnarasam, Jehangir, Neeleshan, Neeluddin, A.U. Rumani recorded conical shaped inflorescences.

The results indicated that maximum length $(43.17 \mathrm{~cm})$, width $(32.23 \mathrm{~cm})$ of the inflorescence and more number of flowers (4242.00) and more number of male flowers per inflorescence (3655.33) were recorded in mango cv. Bangalora, whereas minimum length $(13.17 \mathrm{~cm})$ and width $(10.03 \mathrm{~cm})$ of the inflorescence and less number of flowers (887.33) and less number of male flowers per inflorescence (840.00) were recorded in mango cv. Jehangir (Table 2), however among all varieties / hybrids maximum sex ratio (31.05) (male flower to hermaphrodite flower) was found in cv. Jehangir followed by cv. Baneshan (27.54), while it was minimum in cv. Neelum (1.68). Mukherjee (1997) reported that the ratio of male to perfect flower was strongly influenced by environmental and cultural factors.

The maximum percentage of hermaphrodite flowers and maximum percentage of fruit set per inflorescence $(37.33 \%$ and $35.07 \%$ ) was observed in mango cv. Neelum followed by cv. Kalepad (25.34 \% and $23.82 \%)$, Cherukurasam $(25.33 \%$ and $23.78 \%)$ and Panchadarakalasa $(23.40 \%$ and $21.99 \%)$, whereas it was minimum in mango cv. Baneshan (3.53\%) and (3.35\%) (Table 3 and Fig. 4). These results are in agreement with the findings of Kumar et al., (2014) Kalyanasundaram (1976), Thimmappaiah and Suman (1987) who recorded highest percentageof hermaphrodite flowers per inflorescence in mango cv. Neelum.

In conclusion, the development of mango variety through the selection is important. The study on physio-morphological floral characteristics of mango showed that there have variations among the germplasm. This gives the opportunity to select germplasm on the basis of desirable characters. The improved variety of mango may be developed using the variability of collected genotypes.

\section{Acknowledgement}

Authors are thankful to College of Horticulture, Ananatharajpet, Dr. YSR Horticultural University, West Godhavari for providing the necessary facilities to carry out this research work

\section{References}

De Candolle, A. 1904. Origin of Cultivated Plants. Kegan Paul, Trench, London. IPGRI. 2006. Descriptor for mango (Mangifera indica). International Plant Genetic Resources Institute. Rome, Italy.

Kalyanasundaram, P. 1976. Studies on floral biology in mango (Mangifera indica L. ), AUARA. 6: 36-48.

Kumar, M, Ponnuswami, V, Kumar, P and Saraswathy, S. 2014. Influence of season affecting flowering and physiological parameters in mango. Scientific Research and Essays. 9 (1): 16. 31 ref.

Majumdar, P. K and Sharma, D. K. 1990. Mango. Fruits Tropical and Subtropical.

Mukherjee, S. K. 1997. Introduction; Botany and importance. In: The mango Botany, Production and Uses $1^{\text {st }}$ edition (R. E. Litz Ed.), $C A B$ International, Wallingford, UK. pp. 1-19.

Murti GSR, Upreti KK. 2000. Plant hormones. In: Advances in Plant Physiology, (ed. A. Hemantaranjan), Scientific Publishers. Jodhpur (India). 2000; 3: 109-148.

Naik, K.C and Gangolly, S. R. 1950. A 
monograph on Classification and Nomenclature of South Indian mangoes. Superintendent, Government Press, Madras.

Popenoe, W. 1927. Manual of tropical and sub-tropical fruits. Macmillan, New York, USA.

Singh RN. 1960. Studies on the differentiation and development of fruit buds in mango (Mangifera indica L.) Periodical changes in the chemical composition of shoots and their relation with flower bud differentiation. Horticulture Advances.4:48-59.

Thimmappaiah, CL and Suman, D. 1987. Sex in relation to fruit set and fruit yield in mango Punjab Horticultural Journal. 27: 8-11.

\section{How to cite this article:}

Saheda, M.D., M. Balahussaini, M. Ramaiah and Balakrishna, M. 2019. Study on MorphoPhysical Characters of Mango Flower Varieties / Hybrids in Kodur Agro-Climatic Conditions. Int.J.Curr.Microbiol.App.Sci. 8(03): 28-38. doi: https://doi.org/10.20546/ijcmas.2019.803.005 